\title{
MODEL PENDEKATAN LESSON STUDY UNTUK MENINGKATKAN KETERAMPILAN MENGAJAR MAHASISWA PADA MATA KULIAH MICROTEACHING
}

\author{
1Halim Simatupang ( halim@unimed.ac.id ) \\ 2Aryeni (yanyen.1994@gmail.com ) \\ 1,2Jurusan Pendidikan Biologi FMIPA, Universitas Negeri Medan
}

\begin{abstract}
ABSTRAK
Tujuan penelitian untuk mengetahui efektivitas lesson study dalam meningkatkan keterampilan mengajar calon guru biologi pada Prodi Pendidikan Biologi Unimed. Subjek penelitian adalah mahasiswa Pendidikan Biologi yang mengikuti matakuliah micro teaching berjumlah 9 orang. Prosedur penelitian dalam bentuk kegiatan lesson study yaitu: (1) Plan (perencanaan); (2) Do (pelaksanaan) dan; (3) See (refleksi) yang diintegrasikan dengan mata kuliah micro teaching. Pengumpulan data menggunakan lembar observasi terhadap RPP yang dibuat dan proses pelaksanaan pembelajaran. Analisis data dalam penelitian ini adalah deskriptif. Data yang diperoleh merupakan data kualitatif yang diperoleh dari observasi. Hasil penelitian yang diperoleh yaitu: 1) dalam microplan (menyusun rencana pelaksanaan pembelajaran), dari 7 aspek yang dinilai diperoleh keidealan yaitu: (1) kelengkapan identitas RPP diperoleh 67,8\% menjadi 89,2\%; (2) perumusan tujuan pembelajaran diperoleh 66,6\% menjadi 91,6\%; (3) Uraian materi pokok diperoleh 58,3\% menjadi 83,3\%; (4) metode, strategi dan media pembelajaran diperoleh 66,6\%; menjadi 91,6\%; (5) rancangan langkah-langkah pembelajaran berbasis saintifik diperoleh 66,6\%, menjadi 83,3\%; (6) Penilaian (kognitif, sikap dan keterampilan) diperoleh 75\%, menjadi 90\%; dan (7) sumber belajar diperoleh 75\%, menjadi 87,5. 2) Pelaksanaan (Do) dengan penerapan lesson study terjadi peningkatan yang sangat baik dimana dari 3 aspek yang dinilai memperoleh keidealan yaitu (1) Pendahuluan, 68,7\% kategori Cukup, menjadi 87,5\% kategori Sangat Baik; (2) Inti, 60\%, menjadi 82,5\% Kategori Baik; dan (3) Penutup 62,5\% kategori tidak baik, menjadi 93,7\% kategori Sangat Baik. Simpulannya penerapan pendekatan lesson study pada matakuliah microteaching dapat meningkatkan keterampilan mengajar mahasiswa.
\end{abstract}

Kata Kunci: Lesson study, Microteaching, Keterampilan Mengajar

\begin{abstract}
The study aim to know effectiveness of lesson study to improve teaching skills of biology teacher candidate of the study program biology education at Unimed. This study subject is biology education students' that follow of micro teaching course which amount is nine people. The procedure of study in the form a series of activities lesson study are plan, do, and reflection that integrated with micro teaching course. The data collection is done in this study using sheets of observation toward lesson study constructed and learning implementation process. The data analysis of the study is descriptive. The data was qualitative data obtained from observation. The study results which obtained are: 1) Microplan (to arrange of lesson study), from 7 the aspects regarded as obtained ideals that are: (1) The completeness of the identity of lesson study obtained is 67,8\% into 89,2\%; (2) The formulation of the purpose of learning obtained is 66,6\% into 91,6\%; (3) The description of the subject matter obtained is 58,3\% into 83,3\%; (4) Method, strategy and learning media obtained is 66,6\%; into 91,6\%; (5) the design learning steps based on scientific obtained is 66,6\%, into 83,3\%; (6) Assessment (cognitive, attitude, and skill) obtained is 75\%, into 90\%; and (7) The source of learning obtained is 75\%, into 87,5\%; 2) Implementation (Do) with application of the lesson study occur to increase which very good where from 3 the aspects regarded as obtain ideals are: (1) Introduction, 68,7\% which enough category into 87,5\% very good category; (2) Core, 60\%, into 82,5\% good category; and (3) Closing 62,5\% not good category into 93,7\% very good category. Concluded that the application of approaches the lesson study of the microteaching course can to increase students' teaching skill.
\end{abstract}

Keywords: Lesson Study, Microteaching, Teaching Skill

\section{PENDAHULUAN}

Mengajar bukanlah proses yang sederhana, melainkan proses yang kompleks, dimana guru dituntut untuk mentransfer ilmu pengetahuan, menguasai teknik mengajar agar dapat mengadaptasikan berbagai teknik mengajar kepada siswa yang memiliki berbagai macam tipe belajar serta bakat yang berbeda. Menurut Burton (dalam Sagala, 2003:61) mengemukakan mengajar adalah upaya memberikan stimulus, bimbingan 
pengarahan, dan dorongan kepada siswa agar terjadi proses belajar. Barnawi dan Arifin, M, (2015:13) Mengajar merupakan suatu pekerjaan atau usaha untuk membuat siswa yang diajar itu melakukan kegiatan belajar. Tugas dan tanggung jawab pengajar ialah mengelola pengajaran dengan lebih efektif, dinamis, efisien, dan positif yang ditandai dengan adanaya kesadaran keterlibatan aktif diantara kedua subjek pengajar; guru sebagai penginisiatif awal dan pengarah serta pembimbing, sedangkan siswa sebagai yang mengalami dan terlibat aktif untuk memperoleh perubahan diri dalam mengajar.

Mahasiswa pendidikan biologi yang akan menjadi calon guru bukan hanya dituntut untuk hanya membuat siswanya belajar, melainkan juga dituntut untuk mengajar untuk dirinya sendiri. Mahasiswa dituntut untuk melatih kemampuan dalam merencanakan kegiatan pembelajaran dalam bentuk Rencana Pelaksanaan Pembelajaran (RPP), melaksanakannya dan memantau perubahan-perubahan yang terjadi pada diri siswa. Selama ini proses pembentukan calon guru dalam hal meningkatkan profesionalnya adalah melalui mata kuliah micro teaching. Micro teaching mulai dikembangkan pada awal 1960 di Universitas Stanford (Amobi dan Irwin, 2009:26) ketika paham behaviorisme dalam psikologi mulai mempengaruhi proses pembelajaran. Paham ini menekankan pentingnya umpan balik dalam proses pembelajaran, dimana calon guru yang sedang berlatih menjadi guru yang memiliki prilaku yang benar memperkuat hal-hal yang mengandung respon positif dari orang lain dan menghindari hal-hal yang mengundang respon negatif dari orang lain.

Perkuliahan micro teaching selama ini yang dilaksanakan di Universitas Negeri Medan, khususnya pendidikan biologi dilaksanakan pada semester VI (enam) kendala yang dihadapi selama ini mahasiswa yang mengambil matakuliah micro teaching belum memiliki pengalaman secara rinci, dapat diidentifikasi sebagai berikut: (1) belum memahami cara menyusun RPP, (2) tidak menguasai model/ metode dan strategi pembelajaran, (3) mahasiswa belum pernah mengajar sama sekali sehingga proses perkuliahan tidak dapat berjalan maksimal. Berdasarkan latar belakang tersebut tim peneliti menganggap perlu untuk mengatasi permasalahan belajar mahasiswa di kelas. Mahasiswa perlu dilatih dalam hal penyusunan RPP, model-model pembelajaran dan menumbuhkan kepercayaan diri ketika mengajar. Dalam hal ini peneliti sepakat menerapkan Lesson study untuk meningkatkan kemampuan profesional calon guru dalam mengajar pada matakuliah micro teaching. Sejalan dengan pendapat (Sa'diah, 2010:42; Rintayati, P, 2015:63) lesson study dipandang sebagai salah satu cara meningkatkan inovasi dan kemampuan mengajar calon guru.

Lesson study adalah suatu model pembinaan profesi kependidikan melalui pengkajian pembelajaran secara kolaboratif dan berkelanjutan berlandaskan prinsip-prinsip kolegalitas dan mutual learning untuk membangun komunitas belajar (Hendayana, dkk, 2006:10) "Lesson study is a simple idea. If you want to improve instruction, what could be more obvious than collaborating with fellow teachers to plan, observe, and reflect on lesson" (Cerbin, B dan Kopp, B, 2015:1). Ikhsan, dkk. (2014:253) yang telah melaksanakan lesson study pada mata kuliah microteaching mengatakan "the implication of this study is the need for students to be given early exposure to lesson study so that they can apply it directly to their teaching pratices"

Berdasarkan latar belakang masalah diatas maka tujuan penelitian yaitu: untuk mengetahui efektivitas lesson study dalam meningkatkan keterampilan mengajar calon guru biologi pada Prodi Pendidikan Biologi Universitas Negeri Medan. Penelitian ini diharapkan mampu memberi manfaat 1) meningkatkan kemampuan mahasiswa dalam menyusun RPP, sehingga proses praktik mengajar dalam perkuliahan lebih siap dan maksimal; 2) sebagai salah satu alternatif strategi pembelajaran pada matakuliah microteaching.

\section{METODE PENELITIAN}

Penelitian ini merupakan penelitian deskriptif dengan maksud untuk mengetahui kompetensi calon guru biologi dalam menyusun RPP dan melaksanakan praktik pembelajaran sebelum dan setelah pelaksanaan lesson study serta untuk mengetahui efektifitas pelaksanaan lesson study pada peningkatan kompetensi calon guru biologi dalam menyusun RPP dan melaksanakan praktik mengajar. Penelitian ini dilakukan pada mahasiswa semester VI tahun akademik 2017/2018 program studi Pendidikan Biologi Universitas Negeri Medan disatu kelas microteaching yang berjumlah sembilan orang. Setiap kelompok lesson study terdiri dari tiga 
kelompok yang terdiri dari tiga orang mahasiswa. Setiap kelompok mahasiswa mengikuti 3 tahap yaitu: (1) Plan (perencanaan); (2) Do (pelaksanaan) dan; (3) See (refleksi) yang di integrasikan dengan mata kuliah micro teaching. Seperti terlihat pada Gambar. 1 dibawah ini.

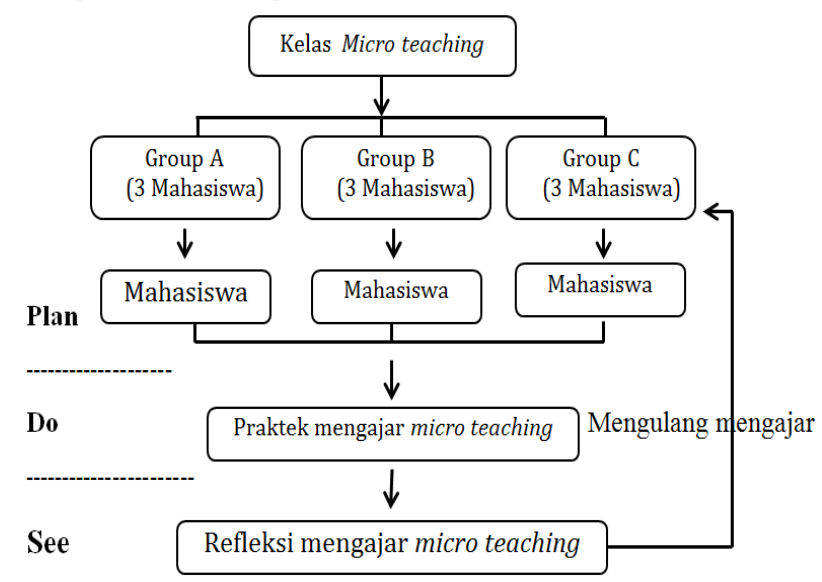

Gambar 1. Integrasi Lesson Study Dalam Perkuliahan Micro Teaching.

\section{- Plan (Perencanaan)}

Pada tahap ini bertujuan untuk membagi kelas micro teaching menjadi kelompok lesson study dimana di kelompok ini mereka akan berdiskusi merancang bersama rencana pelaksanaan pembelajaran, mulai dari menganalisis KI dan KD, memillih metode pembelajaran yang tepat, media pembelajaran sampai bagaimana membuat evaluasi dalam proses pembelajaran. kemudian setiap kelompok mendiskusikan perangkat pembelajaran yang disusun kepada guru mata pelajaran biologi disekolah yang di tunjuk, setelah itu melakukan perbaikan perangkat pembelajaran dari masukan yang diberikan. Selanjutnya setiap kelompok memilih satu orang yang mewakili kelompok tersebut untuk menerapkan rancangan pembelajaran yang telah disusun bersama.

- Do (pelaksanaan)

Mahasiswa melaksanakan praktek mengajar sesuai dengan rancangan yang telah disusun, ketika proses micro teaching berjalan, dosen dan observer melakukan pengamatan, dilakukan penilaian terhadap Rencana Pelaksanaan Pembelajaran (RPP).
Setelah dilakukan praktek mengajar dilaksanakan refleksi. Pada refleksi ini dilakukan diskusi antara mahasiswa dan dosen serta pengamat terhadap hasil tindakan pembelajaran merumuskan dan mengidentifikasi masalah pada pelaksanan serta respon mahasiswa.

\section{Teknik Pengumpulan dan Analisis Data}

Pengumpulan data dilakukan dalam penelitian ini menggunakan lembar observasi terhadap RPP yang dibuat dan proses pelaksanaan pembelajaran. Analisis data dalam penelitian ini adalah deskriptif, yaitu menjelaskan suatu permasalahan gejala, atau keadaan sebagaimana adanya dan bukan menguji hipotesa. Data yang diperoleh dalam penelitian ini adalah data kualitatif yang diperoleh dari observasi. Data yang diperoleh dianalisis dengan langkah-langkah sebagai berikut: (a) Data diperoleh berupa daftar check list yang dirangkum dalam bentuk tabel skala penilaian yang digunakan adalah skala 1-4, dengan keterangan (1) tidak baik, (2) cukup, (3) baik dan (4) sangat baik; (b) Menghitung keberhasilan rancangan pembelajaran dan aplikasinya.

\section{HASIL PENELITIAN}

Data kegiatan hasil evaluasi penilaian Microplan (Penilaian Rencana Pelaksanaan Pembelajaran) pada perkuliahan mikroteaching dengan penerapan model lesson study dapat dilihat pada gambar 1 dibawah ini:

Dari gambar 1 diatas dapat dilihat penerapan model lesson study dapat meningkatkan persiapan mahasiswa dalam menyusun Rencana Pelaksanaan Pembelajaran (RPP) yang baik pada matakuliah microteaching dapat dilihat dari Plan-1 dari 7 aspek yang dinilai memperoleh keidealan yaitu: (1) kelengkapan identitas RPP diperoleh $67,8 \%$; (2) perumusan tujuan pembelajaran diperoleh $66,6 \%$; 3) Uraian materi pokok diperoleh 58,3\%; (4) metode, strategi dan media pembelajaran diperoleh 66,6\%; (5) rancangan langkah-langkah pembelajaran berbasis saintifik diperoleh 66,6\%; (6) Penilaian (kognitif, sikap dan keterampilan) diperoleh 75\%; (dan (7) sumber belajar diperoleh $75 \%$. 
JURNAL BIOLOKUS Vol.1 (2)

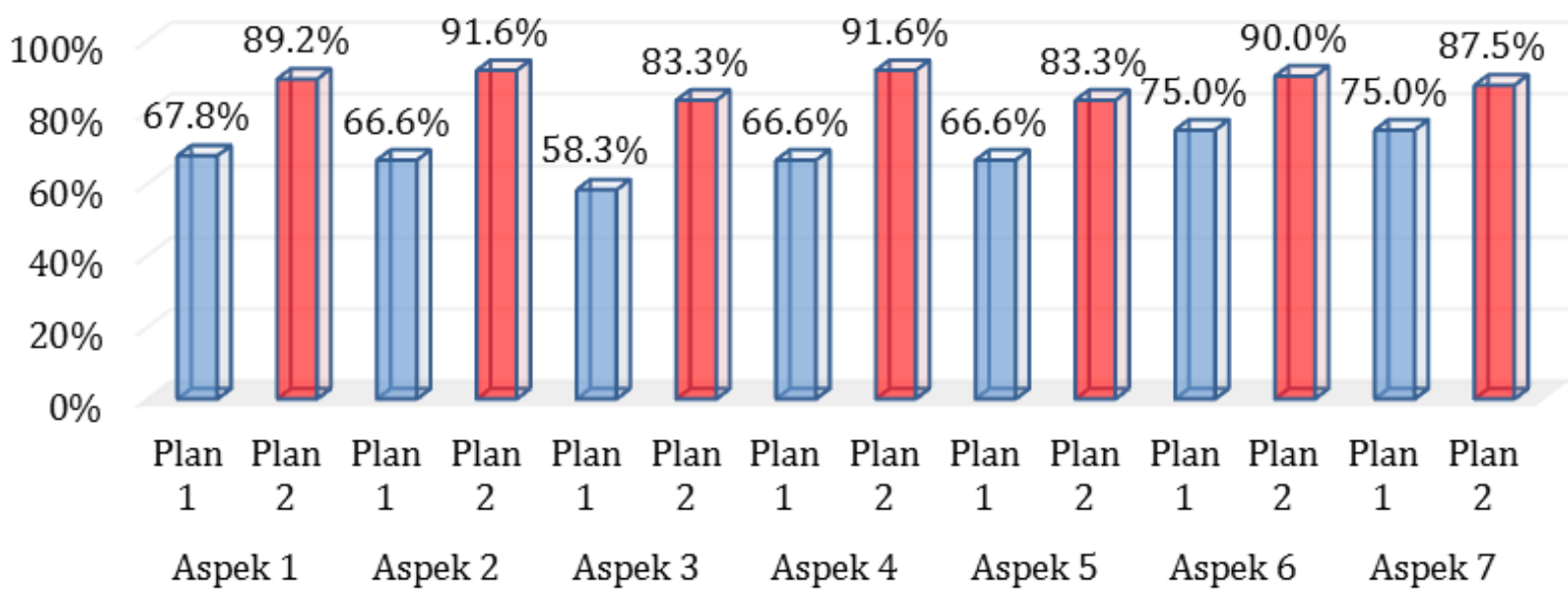

Gambar 2. Penilaian Rencana Pelaksanaan Pembelajaran (RPP).

Keterangan:

$\begin{array}{ll}\text { Aspek 1 } & \text { Kelengkapan Identitas RPP } \\ \text { Aspek 2 } & \text { Perumusan tujuan pembelajaran } \\ \text { Aspek 3 } & \text { Uraian materi pokok } \\ \text { Aspek 4 } & \text { Metode, strategi, media pembelajaran } \\ \text { Aspek 5 } & \text { Rancangan langkah-langkah pembelajaran berbasis saintifik } \\ \text { Aspek 6 } & \text { Penilian (Kognitif, Sikap dan keterampilan) } \\ \text { Aspek 7 } & \text { Sumber Belajar }\end{array}$

Refleksi yang dilakukan setelah penilaian yang dilakukan terhadap Plan-1 yaitu, dosen memberikan masukan kepada mahasiswa untuk memperbaiki RPP yang disusun dimulai dari penyusunan indikator pembelajaran yang sesuai dengan (audience, bihaviore, condition dan degree) serta disesuaikan dengan tagihan pembelajaran, memilih metode pembelajaran yang sesuai dengan materi dan merancang langkah-langkah pembelajaran sesuai dengan sintak dari model pembelajaran yang dipilih, sumber belajar menggunakan lingkungan sekitar, dan pemberian pendidikan karakter. Setelah mendapat masukan mahasiswa berdiskusi dengan rekan kelompoknya untuk merancang pembelajaran selanjutnya sesuai dengan masukan dari dosen pengampuh matakuliah.

Pada Plan-2 terjadi peningkatan rancangan microplan (penyusunan RPP) yang disusun oleh mahasiswa dari 7 aspek yang dinilai memperoleh keidealan yaitu: (1) kelengkapan identitas RPP diperoleh 89,2\%; (2) perumusan tujuan pembelajaran diperoleh 91,6\%; (3) Uraian materi pokok diperoleh 83,3\%; (4) metode, strategi dan media pembelajaran diperoleh 91,6\%;
(5) rancangan langkah-langkah pembelajaran berbasis saintifik diperoleh 83,3\%; (6) Penilaian (kognitif, sikap dan keterampilan) diperoleh 90\%; dan (7) sumber belajar diperoleh 87,5\%. Refleksi yang dilakukan pada plan kedua yaitu penyempurnaan aspek-aspek yang ada dari 7 aspek yang dinilai 5 aspek yang dinilai masuk kategori sangat baik yaitu (1) kelengkapan microplan; (2) perumusan tujuan pembelajaran; (3) metode, strategi dan media; (4) Penilaian; dan (5) sumber belajar, dan 2 aspek masuk kategori baik yaitu (1) Uraian materi pokok dan (2) rancangan langkah-langkah pembelajaran. Pada rancangan plan-2 ini dosen memberi masukan untuk lebih menyempurnakan langkah-langkah pembelajaran dibuat lebih menekankan keterampilan literasi siswa dan penguatan pendidikan karakter dan berorientasi kepada siswa yang lebih aktif, untuk uraian materi pokok lebih ditekankan kepada rincian materi konsep, fakta dan hukum.

Data kegiatan hasil observasi praktek mengajar perkuliahan mikroteaching dengan penerapan model lesson study dapat dilihat pada gambar 2 dibawah ini: 


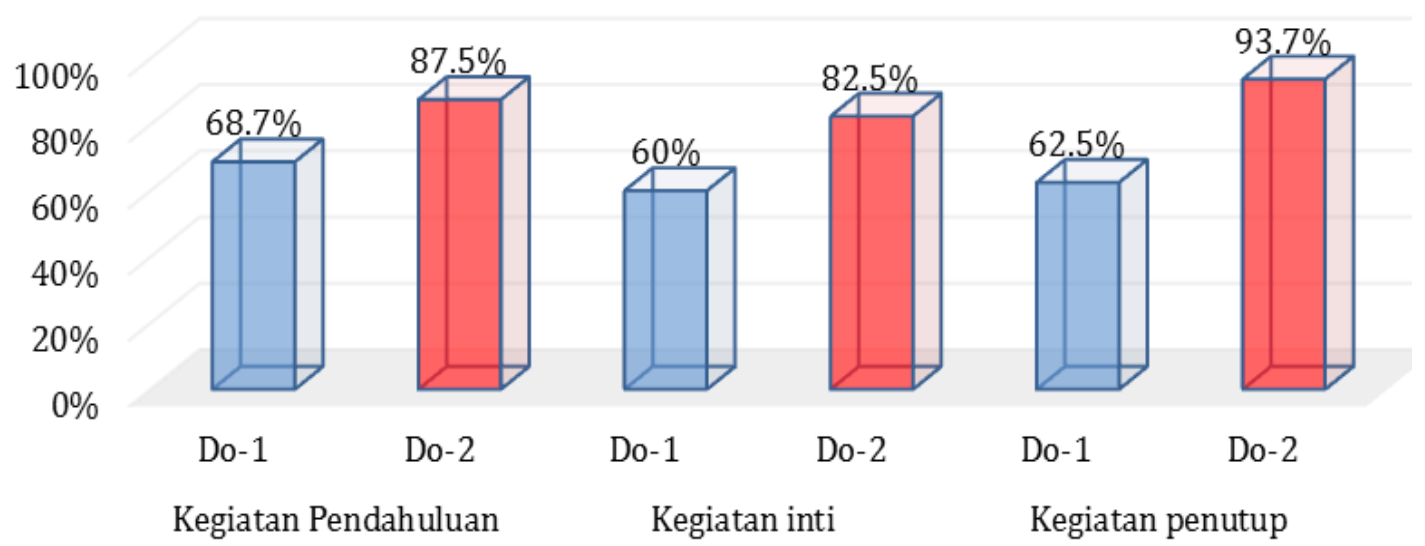

Gambar 3. Hasil Observasi Praktek Mengajar Mahasiswa.

Dari gambar 3 diatas dapat dilihat penerapan model lesson study dapat meningkatkan nilai pelaksanaan pembelajaran yang baik pada matakuliah microteaching dapat dilihat dari Do-1 dari 3 aspek yang dinilai memperoleh keidealan yaitu : (1) pendahuluan, diperoleh $68,7 \%$ dengan kategori Cukup ; (2) kegiatan Inti, diperoleh 60\%; dan (3) kegiatan penutup diperoleh 62,5\% kategori tidak baik. Refleksi yang dilakukan setelah penilaian dengan calon guru yang dilakukan terhadap Do-1 yaitu pada kegiatan pendahuluan memperbaiki apersepsi dan menyampaikan tujuan pembelajaran, pada kegiatan inti penguasaan materi perlu ditingkatkan, urutan penyajian harus sistematis sesuai sintak dari model pembelajaran, pemberian penguatan pada aspek yang penting dan diharapkan calon guru menggunakan media pembelajaran yang bisa mengaktifkan siswa. Pada kegiatan penutup calon guru perlu melakukan refleksi terhadap kegiatan pembelajaran yang baru dilaksanakan dan pemberian tindak lanjut untuk meningkatkan pemahaman dan pendalaman materi oleh siswa dirumah.

Pada Do-2 terjadi peningkatan kemampuan mengajar calon guru dilihat dari 3 aspek yang dinilai memperoleh keidealan yaitu : (1) kegiatan pendahuluan, diperoleh 87,5\% dengan kategori Sangat Baik ; (2) kegiatan inti, diperoleh 82,5\% dengan Kategori Baik; dan (3) kegiatan penutup diperoleh 93,7\% dengan kategori Sangat Baik. Refleksi yang dilakukan setelah penilaian dengan calon guru yang dilakukan terhadap Do-2 yaitu memberikan saran untuk konsisten dalam menjalankan RPP yang sudah dirancang, tidak lupa berlatih dirumah sebelum tampil dan mempertahankan prestasinya saat ini.

\section{PEMBAHASAN}

Bagi calon guru, merancang RPP dengan baik dan benar merupakan hal yang baru, karena biasanya mahasiswa hanya memperoleh pengetahuan saat mengambil matakuliah strategi belajar mengajar sehingga kesempurnaan dari RPP yang disusun jauh dari harapan. Dengan penerapan pendekatan lesson study mahasiswa secara berkelompok berdiskusi dengan temannya untuk merancang RPP dengan baik, hasilnya juga belum sempurna dapat dilihat dari Plan-1 yang dirancang.

Hasil refleksi yang dilakukan dosen pengampu dengan mahasiswa calon guru, mahasiswa diminta mencari guru senior untuk membantu mahasiswa dalam menyusun RPP yang baik sesuai dengan pendapat (Rustono, WS . 2008; Dirjend Dikti, 2009) pembinaan guru yang bersifat kolaboratif dan kolegalitatif dapat dimanfaatkan sebagai model bimbingan mengajar dosen terhadap mahasiswa. Dengan masukan dari refleksi Plan-1 yaitu penyusunan indikator pembelajaran yang sesuai dengan (audience, bihaviore, condition dan degree) serta disesuaikan dengan tagihan pembelajaran, memilih metode pembelajaran yang sesuai dengan materi dan merancang langkah-langkah pembelajaran sesuai dengan sintak dari model pembelajaran yang dipilih, sumber belajar mengunakan lingkungan sekitar, dan pemberian pendidikan karakter.

Pada rancangan plan-2 ini dosen memberi masukan untuk lebih menyempurnakan langkahlangkah pembelajaran dibuat lebih menekankan pendidikan karakter dan berorientasi kepada siswa yang lebih aktif, untuk uraian materi pokok lebih ditekankan kepada rincian materi konsep, fakta dan hukum. Dari temuan ini dapat disimpulan 
penerapan lesson study I dapat meningkatkan kemampuan mahasiswa dalam menyusun rencana pelaksanaan pembelajaran, temuan ini sejalan dengan pendapat Slamet Mulyana (2009) yang menyatakan bahwa setelah mengikuti pendidikan dan pelatihan lesson study, terjadi peningkatan kemampuan peserta dalam menyusun RPP dengan menerapkan model pembelajaran yang relevan dengan kompetensi dasar yang hendak dicapainya dan visi, misi, dan tujuan sekolah.

Pelaksanaan (Do) dengan penerapan lesson study terjadi peningkatan yang sangat baik dimana Do-1 dari 3 aspek yang dinilai memperoleh keidealan yaitu (1) Pendahuluan, 68,7\% kategori Cukup ; (2) Inti, 60\%; dan (3) Penutup 62,5\% kategori tidak baik. Refleksi yang dilakukan setelah penilaian dengan calon guru yang dilakukan terhadap Do-1 yaitu pada kegiatan pendahuluan memperbaiki apersepsi dan menyampaikan tujuan pembelajaran, pada kegiatan inti penguasaan materi perlu ditingkatkan, urutan penyajian harus sistematis sesuai sintak dari model pembelajaran, pemberian penguatan pada aspek yang penting dan diharapkan calon guru menggunakan media pembelajaran yang bisa mengaktifkan siswa. Pada kegiatan penutup calon guru perlu melakukan refleksi terhadap kegiatan pembelajaran yang baru dilaksanakan dan pemberian tindak lanjut untuk meningkatkan pemahaman dan pendalaman materi oleh siswa dirumah. Pada Do-2 terjadi peningkatan kemampuan mengajar calon guru dilihat dari 3 aspek yang dinilai memperoleh keidealan yaitu (1) Pendahuluan, 87,5\% kategori Sangat Baik ; (2) Inti, 82,5\% Kategori Baik; dan (3) Penutup 93,7\% kategori Sangat Baik. Dari kegaitan diatas dapat dilihat bahwa peningkatannya sangat signifikan sesuai pendapat Ihsan, dkk (2014) pendekatan lesson study pada matakuliah mikroteaching membuat mahasiswa mampu berinovasi dan meningkatkan keterampilan mengajarnya.

\section{SIMPULAN}

Berdasarkan paparan data dan pembahasan maka dapat disimpulkan bahwa lesson study memiliki efektivitas dalam meningkatkan keterampilan mengajar mahasiswa dalam matakuliah microteaching dapat dilihat dari peningkatan kemampuan mahasiswa dalam microplan (menyusun rencana pelaksanaan pembelajaran), dari 7 aspek yang dinilai diperoleh keidealan yaitu: (1) kelengkapan identitas RPP diperoleh 67,8\% menjadi 89,2\%; (2) perumusan tujuan pembelajaran diperoleh $66,6 \%$ menjadi 91,6\%; (3) uraian materi pokok diperoleh 58,3\% menjadi 83,3\%; (4) metode, strategi dan media pembelajaran diperoleh 66,6\%; menjadi 91,6\%; (5) rancangan langkah-langkah pembelajaran berbasis saintifik diperoleh 66,6\%, menjadi 83,3\%; (6) penilaian (kognitif, sikap dan keterampilan) diperoleh 75\%, menjadi 90\%; dan (7) sumber belajar diperoleh 75\%, menjadi 87,5\%.

Pelaksanaan (Do) dengan penerapan lesson study terjadi peningkatan yang sangat baik dimana dari 3 aspek yang dinilai memperoleh keidealan yaitu (1) pendahuluan, 68,7\% kategori Cukup, menjadi $87,5 \%$ kategori Sangat Baik; (2) inti, 60\%, menjadi 82,5\% Kategori Baik; dan (3) penutup $62,5 \%$ kategori tidak baik, menjadi 93,7\% kategori Sangat Baik. Dapat disimpulkan penerapan pendekatan lesson study pada matakuliah microteaching dapat meningkatkan keterampilan mengajar mahasiswa.

\section{REFERENSI}

Anggara, Rian \& Chotimah, Umi. 2012. Penerapan Lesson Study Berbasis Musyawarah Guru Mata Pelajaran (MGMP)Terhadap Peningkatan Kompetensi Guru PKn SMP SeKabupaten Okan Ilir. Jurnal Forum Sosial, Vol V. No.2, September 2012; Hal:188-197.

Anonim. 2015. Steps in Micro Teacing Cycle. [online] tersedia di Tujuan http://wikieducator.org/Micro teaching. Diakses 22 desember 2015

Amonbi, Funmin A \& Lesli, Ingrwin. 1990. "Implementing On-Campus Micrteaching to Elitcit Preservice Teachers Reflection On Teaching Action: Fres Perspective on an Establishesed Practice" dalam Journal of the scholarsip of Teaching and Learning, Vol 9, No. 1. Januari 2009.

Asri, Zainal. 2011. Micro teaching. Disertasi dengan Pedoman Lapangan. Jakarta: Rajawali Press.

Barnawi dan Arifin, M, 2015. Micro Teachinng. Teori dan Praktik Pengajaran yang Efektif dan Kreatif. Jogjakarta: Ar-Ruzz Media. 
JURNAL BIOLOKUS Vol.1 (2)

Brown, George. 1991. Menggajar Mikro: Program Keterampilan Mengajar. Terjemahan Laurens Kaluge. Surabaya: Airlangga University Press.

Cerbin, Bill \& Kopp, Bryan. 2015. Lesson Study Project . [online] Tersedia di http://www.uwlax.edu/sotl/lsp/overview.h tm. La Crosse: University of Wisconsin.

Dirjend Dikti. 2009. Panduan Penyusunan Program Perluasan Dan Penguatan Lesson Study Di LPTK (Lesson study Dissemination Program for Strengthening Teacher Education in Indonesia - LEDIPSTI) Jakarta: Direktorat Ketenagaan Dirjen Dikti Depdiknas.

Hendayana, dkk, 2006. Lesson Study: Suatu Strategi Untuk meningkatkan Keprofesionalan Pendidikan (Pengalaman IMSTEP-JICA) Bandung: UPI Press.

Ihsan, Zanaton H, Zakaria, Efendi, Daud Yusoff. 2014. Model od Lesson Study Approach during Microteaching" Fakulty Of Education. Universiti Kebangsaan Malaysia. Juornal International Education Studies. Vol 7 No. 13. 2014. Hal:253-260.

Nurlaila.2009. Pengajaran Micro: Suatu Pendekatan Menuju Guru Profesional" dalam Ta'dib Vol.12, No.1 (juni 200) Hal: 72-80.

Rintayati, Peduk. 2015. Lesson study model pembelajaran Kooperatif Untuk Meningkatkan Kemampuan Inquiry Training Materi Konsep Asam-Basa Pada Mahasiswa PGSD FKIP UNS. Jurnal Profesi Pendidikan. Volume 2, Nomor 1 , Mei 2015. Hal: 59-72.

Rustono.W.S.2008. Meningkaatkan Kemampuan Mahasiswa Menerapkan Strategi Pembelajaran Melalui lesson Studi di Sekolah Dasar. JURNAL Pendidikan Dasar “ Nomor: 10 - Oktober 2008.

Sa'dijah.2010. Penerapan Lesson study dan Pemberian Pengalaman Langsung di Sekolah pada Mahasiswa Peserta "Teaching Senior High School Mathematics In English". Prosiding Seminar Nasional Lesson Study 4: Peran Lesson Study Dalam Meningkatkan Profesionalitas Pendidik dan Kualitas Pembelajaran Secara Berkelanjutan (Continuing Professional Development), 42-49.

Sagala, Syaiful. 2003. Konsep dan Makna Pembelajaran: Untuk Membantu
Memecahkan Problematika Belajar dan Mengajar. Bandung: Alfabeta.

Setyawan, Dodiet Aditiya, 2010. Konsep Pengajaran Micro(micro teaching). Hand out Mata kuliah Micro Teaching Jurusan Kebidanan Tahun Akademik 2010/2011. Surakarta: Poltekes Surakarta.

Slamet Mulyana. 2009. Dampak Pendidikan Dan Pelatihan Lesson Study Terhadap GuruGuru.Online:

http://www.lpmpjabar.go.id/index.php?o ption=com content\&view

article \&catid $=40 \% 3$ Apendartikel\&id=181\%3Adampak-pendidikandan-pelatihan-lesson-study-terhadapguru-guru\&Itemid $=63$.

Diakses 1 September 2018

Sukirman, Dadang. 2012. Pembelajaran Micro Teaching. Jakarta: Direktorat Jenderal Pendidikan Islam, Kementerian Agama RI.

Thobroni, Muhammad. 2015. Belajar dan pembelajaran "Teori dan Praktik. Jogjakarta: Ar-Ruzz Media. 